\title{
EVALUATION OF OX-LDL AND EXTRACELLULAR SUPEROXIDE DISMUTASE IN HEPATITIS C VIRUS PATIENTS BEFORE AND AFTER DIRECT-ACTING ANTIVIRAL THERAPY
}

By

\section{Mahmoud Mohamed Abou El-Makarem, Abd El-Aziz Abd El-Rahman El-Nokaly, Sayed Farouk Mohamed*, Ibrahim Hassan Mohammed and Ahmed Mahrous Ahmed Ibrahim}

Department of Medical Biochemistry and Tropical Medicine*, Faculty of Medicine, Al Azhar University, Cairo, Egypt

E-mail: Sayed.faroukma@ azhar.edu.eg

\begin{abstract}
Background: Hepatitis C virus (HCV) lifecycle is closely connected to host cell lipid metabolism, from cell entry, through viral RNA replication to viral particle production and formation/assembly.

Objective: To determine the serum levels of ox-LDL, total antioxidant capacity and superoxide dismutase, and evaluate their role in $\mathrm{HCV}$ hepatitis patients. In addition, the effect of direct-acting antiviral therapy on their levels was evaluated.

Patients and Methods: This study included forty chronic hepatitis C (genotype 4) patients. Blood samples were taken from the patients before and after taking sofosbuvir $(400 \mathrm{mg}$ ) and daclatsvir $60 \mathrm{mg}$; one time daily orally for 24 weeks. Forty apparently healthy personnel were used as control group.

Results: Serum TAC in chronic HCV hepatitis patients were significantly low before treatment as compared to the control group. Serum levels of ox-LDL were significantly high in patients before treatment and after treatment as compared to control group. Antioxidants supplementations and direct antiviral drugs did not affect the levels of ox-LDL significantly. Serum levels of extracellular SOD were significantly higher in control group, than levels in $\mathrm{HCV}$ patients before treatment and after treatment. Treatment did not restore the levels of serum SOD in patients. Direct-acting antiviral agents had a sustained virological response in the chosen group of patients.
\end{abstract}

Conclusions: Direct-acting antiviral agents did not normalize serum levels of ox-LDL and extracellular SOD. In addition, the currently used antioxidants did not decrease the oxidative changes in LDL.

Key words: Ox-LDL, total antioxidant capacity, superoxide dismutase, HCV hepatitis, direct antiviral therapy, sofosbuvir, daclatsvir.

\section{INTRODUCTION}

Hepatitis $\mathrm{C}$ virus (HCV) infection is the leading cause of liver diseases worldwide. Novel therapies have been developed and became available since 2014. These treatments are based on the so-called direct acting antivirals (DAAs). DAAs target viral nonstructural (NS) proteins, including NS3 protease, the NS5B polymerase, and the NS5A protein. (Janardhan and Reau, 2015). 
HCV infection commonly causes progressive liver diseases that deteriorate from chronic inflammation to fibrosis, cirrhosis and even to hepatocellular carcinoma.. The mechanisms of HCVinduced inflammation involve classic pathogen pattern recognition; inflammasome activation, intrahepatic inflammatory cascade response, and oxidative and endoplasmic reticulum stress (Li et al., 2018).

$\mathrm{HCV}$ induces oxidative/ nitrosative stress from multiple sources, including inducible nitric oxide synthase, the mitochondrial electron transport chain, hepatocyte NADPH oxidases, and inflammation, while decreasing glutathione. Oxidation reaction and reactive oxygen species (ROS) induce chemical modification of the proteins and lipids in plasma LDL transforming it to the abnormal oxidized-LDL (ox-LDL). Ox-LDL is not recognized by the liver LDL receptors but is taken up by lectinlike ox-LDL receptor-1 (LOX-1) present in macrophages, natural killer cells, and vascular endothelial cells. Its association with ox-LDL induces the activation of NF-kappa-B. Ox-LDL induces direct inflammatory response due to the activated respiratory burst and production of more ROS. LOX-1 is also involved in systemic leukocyte activation in sepsis. Systemic leukocyte activation represents a crucial factor in the impairment of the microcirculation of different tissues, causing multiple organ failure and subsequently death (Choi, 2012).

$\mathrm{HCV}$ induces oxidative stress in infected cells. Superoxide dismutases (SODs) provide an important defense against oxidative/ nitrosative stress. Three isozymes of SOD are expressed by cells. SOD1 binds copper and zinc ions and is primarily localized to the cytoplasm. SOD 2 is located in the mitochondrial matrix where it represents the first line of antioxidant defense against superoxide anions produced as byproducts of oxidative phosphorylation (Holley et al., 2011).

Makino et al (2016) demonstrated that ox-LDL decreases EC-SOD mRNA and protein levels by binding to lectin-like oxidized LDL receptor-1 (LOX-1).

Overexpression of $\mathrm{Cu}, \mathrm{Zn}-\mathrm{SOD}$ (SOD1) and/or catalase attenuates the cell proliferation of human smooth muscle cells caused by ox-LDL stimulation ( $\mathrm{Lin}$ et al., 2007).

The aim of this work was to determine the serum levels of ox-LDL, total antioxidant capacity and superoxide dismutase, and evaluate their role in $\mathrm{HCV}$ hepatitis patients. In addition, the effect of direct-acting antiviral therapy, sofosbuvir (SOF) in combination with daclatsvir on their levels in serum was evaluated.

\section{SUBJECTS AND METHODS}

This study included 40 male patients with chronic hepatitis $\mathrm{C}$ genotype 4 and 40 male controls. Patients were referred from Al-Hussain and Sayed Galal, Al Azhar University Hospitals, and Virology unit, Al-Haram Hospital, Ministry of Health; Egypt. The Ethical Committee of Al-Azhar University approved the protocol of the work. The protocol of the work was explained to all participants and a written medical consent was obtained. Control group: Included forty subjects showing negative $\mathrm{HCV} \mathrm{Ab}$, were selected and assigned as a control group. 
Exclusion criteria: Subjects suffering from any systemic disease or autoimmune disease were excluded from the study. In addition, subjects with BMI $>30 \mathrm{~kg} / \mathrm{m} 2$, those positive HBV or have taken HBV vaccine, smokers, drug addicts and subjects suffering from hepatocellular carcinoma or any other malignancies were excluded from the study.

Inclusion criteria: Only patients with HCV hepatitis diagnosed by quantitative PCR were included in this study.

Anthropometric body Measurements included weight, height, BMI, triceps skin fold, mid arm circumference and waist circumference were done for patients and control group and were matched.

All the patients were taking glutathione (50 mg daily orally), zinc as zinc oxide (11 mg orally once daily), vitamin $\mathrm{A}$ as retinyl acetate; (700 micrograms orally once daily), vitamin $\mathrm{C}$ ( $0.5 \mathrm{~g}$ orally once daily), and vitamin $\mathrm{E}$ as $\alpha$-tocopherol (15 milligrams daily orally), and selenium as sodium selenate $(100 \mu \mathrm{g}$ daily orally)

Patients were treated orally with the combination of sofosbuvir (a nucleotide polymerase inhibitor) (400 $\mathrm{mg}$ one time daily) and daclatasvir, a first-in-class NS5A replication complex inhibitor (60 $\mathrm{mg}$, one time daily for 24 weeks $-\mathrm{Pol}$ et al., 2016).

Blood samples were obtained from patients and healthy controls after 12 hours fasting for serum separation. Serum was used for estimation of liver function tests, total proteins, albumin, oxidized low-density lipoprotein, superoxide dismutase, total antioxidant capacity and quantitative PCR. For HCV was done for all included subjects; before and after treatment.

Total proteins, albumin, alanine transaminase (ALT), aspartate transaminase(AST) and alkaline phosphatase (AP) were performed on Roche/Hitachi 902 auto analyzer, Roche Diagnostic, Germany by using kits supplied by Roche Diagnostic, Germany.

Total antioxidative capacity was measured colorimetrically using a kit supplied from Biodiagnostic Research Agents, Cairo. Total plasma antioxidative capacity was determined by the reaction of antioxidants in the sample with a defined amount of exogenously provided hydrogen peroxide (H2O2). The antioxidants in the sample eliminate a certain amount of $\mathrm{H} 2 \mathrm{O} 2$, The residual $\mathrm{H} 2 \mathrm{O} 2$ was determined colorimetrically by an enzymatic reaction which involves the conversion of 3, 5, dichloro-2-hydroxy benzene sulphonate to a colored product which was measured at $505 \mathrm{~nm}$ (Koracevic et al., 2001).

Quantitative PCR technique was used is real time PCR by applied biosystem 7500 , kit is qiagen.

Superoxide dismutase levels in serum were determined by a kit supplied from Biodiagnostic Research Agents, Cairo. The assay is based on the ability of the enzyme to inhibit the phenazinemethosulphate- mediated reduction of nitrobluetetrazolium dye (Nishikimi et al., 1972).

Oxidized-LDL in serum was measured using WKEA human oxidized LDL ELISA kit supplied from WKEA MED SUPPLIES CORP, USA. Competitive 
ELISA procedure is based on the monoclonal antibody specific to human ox-LDL. Oxidized LDL in the sample competes with a fixed amount of oxidized LDL bound to the microtiter well for the binding of the biotin- labeled specific antibodies. After a washing step that removes unreactive sample components, the biotin-labeled antibody bound to the well is detected by HRP-conjugated streptavidin. After a second incubation and an additional washing step, the bound conjugate is detected by reaction with 3 ,
3', 5, 5'-tetramethylbenzidine (TMB). The reaction is stopped by adding acid to give a colorimetric endpoint that is read spectrophotometrically (Holvoet et al., 2001).

\section{Statistical analysis:}

Results were expressed as Mean \pm standard deviation (SD). Comparison between groups was done using Student's t test with significance defined as $p \leq 0.05$.

\section{RESULTS}

There is no statistically significant difference between studied groups as regard Anthropometric measurement Age, weight, height, BMI, triceps skin fold, mid arm circumference and waist circumference of all subjects were done (Table 1).

Table (1): Anthropometric body measurements in control group and HCV hepatitis patients before and after treatment

\begin{tabular}{|c|c|c|c|c|c|c|c|}
\hline Parameters & $\begin{array}{l}\text { Age } \\
\text { (years) }\end{array}$ & $\begin{array}{l}\text { Weight } \\
\text { (kg) }\end{array}$ & $\begin{array}{l}\text { Height } \\
(\mathrm{cm})\end{array}$ & $\begin{array}{l}\text { BMI } \\
\left(\mathrm{kg} / \mathrm{m}^{2}\right)\end{array}$ & $\begin{array}{l}\text { Skin } \\
\text { fold } \\
(\mathrm{cm})\end{array}$ & $\begin{array}{l}\text { Mid arm } \\
\text { circum- } \\
\text { ference } \\
(\mathrm{cm})\end{array}$ & $\begin{array}{l}\text { Waist } \\
\text { circum- } \\
\text { ference } \\
(\mathrm{cm})\end{array}$ \\
\hline Control & $\begin{array}{l}49.9 \\
\pm 8.23\end{array}$ & $\begin{array}{l}78.2 \\
\pm 6.81\end{array}$ & $\begin{array}{l}170.65 \\
\pm 3.66\end{array}$ & $\begin{array}{l}26.8 \\
5 \pm 2.03\end{array}$ & $\begin{array}{l}1.18 \\
\pm 0.26\end{array}$ & $\begin{array}{l}22.8 \\
\pm 1.63\end{array}$ & $\begin{array}{l}92.5 \\
\pm 6.7\end{array}$ \\
\hline $\begin{array}{l}\text { HCV } \\
\text { patients } \\
\text { before } \\
\text { treatment }\end{array}$ & $\begin{array}{l}57.6 \\
\pm 7.44\end{array}$ & $\begin{array}{l}68.55 \\
\pm 12.25\end{array}$ & $\begin{array}{l}168.1 \\
\pm 5.3\end{array}$ & $\begin{array}{l}24.31 \\
\pm 4.13\end{array}$ & $\begin{array}{l}1.24 \\
\pm 0.52\end{array}$ & $\begin{array}{l}21.4 \\
\pm 2.65\end{array}$ & $\begin{array}{l}97.4 \\
\pm 14.22\end{array}$ \\
\hline $\begin{array}{l}\text { HCV } \\
\text { patients } \\
\text { after } \\
\text { treatment }\end{array}$ & $\begin{array}{l}57.6 \\
\pm 7.44\end{array}$ & $\begin{array}{l}73.55 \\
\pm 9.26\end{array}$ & $\begin{array}{l}168.1 \\
\pm 5.3\end{array}$ & $\begin{array}{l}26.1 \\
\pm 2.63\end{array}$ & $\begin{array}{l}1.26 \\
\pm 0.32\end{array}$ & $\begin{array}{l}21.92 \\
\pm 1.94\end{array}$ & $\begin{array}{l}97.7 \\
\pm 14.83\end{array}$ \\
\hline
\end{tabular}

Biochemical Results: Serum total proteins levels were $7.12 \pm 0.73 \mathrm{~g} / \mathrm{dl}$ in the control group, $6.72 \pm 0.58$ and $6.55 \pm 0.84$ $\mathrm{g} / \mathrm{dl}$ in HCV hepatitis patients before and after treatment respectively. Serum total proteins were not significantly lower in hepatitis patients.

Serum albumin level was 5.76$\pm 0.74 \mathrm{~g} / \mathrm{dl}$ in the control group. Serum albumin levels were $4.01 \pm 0.44$ and 3.79 $\pm 0.26 \mathrm{~g} / \mathrm{dl}$ in $\mathrm{HCV}$ hepatitis patients before and after treatment respectively. Serum albumin level was significantly lower in HCV patients.

Serum alanine aminotransferase level was $23.7 \pm 4.5 \mathrm{U} / \mathrm{dl}$ in the control group. Serum alanine aminotransferase levels were $84 \pm 8.3$ and $80.45 \pm 14.9 \mathrm{U} / \mathrm{dl}$ in $\mathrm{HCV}$ hepatitis patients before and after treatment respectively. Serum alanine 
aminotransferase levels were significantly higher in HCV patients before and after treatment.

Serum aspartate aminotransferase level was $25.2 \pm 3.1 \mathrm{U} / \mathrm{dl}$ in the control group. Serum alanine aminotransferase levels were $196 \pm 10.8$ and $89.8 \pm 14.7 \mathrm{U} / \mathrm{dl}$ in $\mathrm{HCV}$ hepatitis patients before and after treatment respectively. Serum aspartate aminotransferase levels were significantly higher in HCV patients before and after treatment.Serum alkaline phosphatase level was $63.8 \pm 16.3 \mathrm{U} / \mathrm{L}$ in the control group. Serum alkaline phosphatase levels were $196 \pm 38$ and $178 \pm 43 \mathrm{U} / \mathrm{L}$ in $\mathrm{HCV}$ hepatitis patients before and after treatment respectively. Serum alkaline phosphatase level was significantly higher in $\mathrm{HCV}$ patients.

Serum PCR in control group was $<15$ $\mathrm{IU} / \mathrm{ml}$ and $399521 \pm 215675 \mathrm{IU} / \mathrm{ml}$ in HCV hepatitis patients before treatment (Table 2).

Table (2): Serum total proteins, albumin, aminotransferases, alkaline phosphatase and PCR in control group and HCV hepatitis patients before and after treatment (mean \pm SD)

\begin{tabular}{|l|l|l|l|l|l|l|}
\hline Rarameters & $\begin{array}{l}\text { AST } \\
\text { U/dl }\end{array}$ & $\begin{array}{l}\text { ALT } \\
\text { U/dl }\end{array}$ & $\begin{array}{l}\text { ALP } \\
\text { U/L }\end{array}$ & $\begin{array}{l}\text { PCR } \\
\text { IU/ml }\end{array}$ & $\begin{array}{l}\text { Serum } \\
\text { total } \\
\text { proteins } \\
\text { g/dl }\end{array}$ & $\begin{array}{l}\text { Serum } \\
\text { albumin } \\
\text { g/dl }\end{array}$ \\
\hline Control & 25.2 & 23.7 & 63.8 & $<15$ & 7.12 & $5.76 \pm 0.74$ \\
& \pm 3.1 & \pm 4.5 & \pm 16.3 & & \pm 0.73 & \\
\hline $\begin{array}{l}\text { HCV } \\
\text { hepatitis } \\
\text { patients } \\
\text { before } \\
\text { treatment }\end{array}$ & 104 & 84 & 196 & 399521 & 6.72 & 4.01 \\
& 10.8 & \pm 8.3 & \pm 38 & \pm 215675 & \pm 0.58 & \pm 0.44 \\
\hline $\begin{array}{l}\text { HCV } \\
\text { hepatitis } \\
\text { patients } \\
\text { after } \\
\text { treatment }\end{array}$ & \pm 9.8 & 80.45 & 178 & $<15$ & 6.55 & \\
\hline
\end{tabular}

Total serum antioxidant capacity levels were $1.61 \pm 0.26,1.21 \pm 0.28$ and $2.2 \pm 0.38$ $\mathrm{mmol} / \mathrm{liter}$ in the control group, and $\mathrm{HCV}$ hepatitis patients before and after treatment respectively. Serum TAC levels in chronic HCV hepatitis patients were significantly low before treatment. While after treatment which included antioxidants were significantly high as compared to control group and before treatment (Table 3). 
Table( 3) :Serum total anti-oxidant capacity (mmol/liter) in control group and HCV hepatitis patients before and after treatment

\begin{tabular}{|l|c|c|c|}
\hline Groups & Control & $\begin{array}{c}\text { HCV hepatitis } \\
\text { patients before } \\
\text { treatment }\end{array}$ & $\begin{array}{c}\text { HCV hepatitis } \\
\text { patients after } \\
\text { treatment }\end{array}$ \\
\hline Marameters & $1.61 \pm 0.26$ & $1.2 \pm 0.28$ & $2.2 \pm 0.38$ \\
\hline Control & $\begin{array}{c}\mathrm{t} \text { test } \\
\mathrm{p} \text { value }\end{array}$ & 6.33 & 7.74 \\
\hline $\begin{array}{l}\text { HCV before } \\
\text { treatment }\end{array}$ & $\begin{array}{c}\mathrm{t} \text { test } \\
\mathrm{p} \text { value }\end{array}$ & --.001 & $<0.001$ \\
\hline
\end{tabular}

Serum levels of ox-LDL $(\mu \mathrm{g} / \mathrm{L})$ were $58.64 \pm 6.44,70.21 \pm 10.59$ and $68.48 \pm 9.12$ in the control group, and HCV hepatitis patients before and after treatment respectively. Serum levels of ox-LDL were significantly high in HCV hepatitis patients as compared to control group. Antioxidants supplementations and direct antiviral drugs did not affect the levels of ox-LDL significantly in HCV hepatitis patients (Table 4).

Table (4): Serum levels of ox-LDL $(\mu \mathrm{g} / \mathrm{L})$ in control group and HCV hepatitis patients before and after treatment

\begin{tabular}{|l|l|l|l|}
\hline Groups & Control & $\begin{array}{l}\text { HCV hepatitis patients } \\
\text { before treatment }\end{array}$ & $\begin{array}{l}\text { HCV hepatitis patients } \\
\text { after treatment }\end{array}$ \\
\hline Mean & 58.64 & 70.21 & 68.48 \\
\pm SD & \pm 6.44 & \pm 10.59 & \pm 9.12 \\
\hline Control & $\mathrm{t}$ test & 5.97 & 5.57 \\
& $\mathrm{p}$ value & $<0.001$ & $<0.001$ \\
\hline HCV before & $\mathrm{t}$ test & & 0.79 \\
treatment & $\mathrm{p}$ value & & 0.1 \\
\hline
\end{tabular}

Serum levels of SOD (U/ml) were $15.03 \pm 4.14,8.6 \pm 1.1$ and $10.33 \pm 1.6$, in the control group, and HCV hepatitis patients before and after treatment respectively.
Serum levels of extracellular SOD were significantly low in $\mathrm{HCV}$ hepatitis patients before and after treatment as compared to the control group (Table 5).

Table (5): Serum levels of SOD (U/ml) in control group and HCV hepatitis patients before and after treatment

\begin{tabular}{|l|l|l|l|}
\hline Groups & Control & $\begin{array}{l}\text { HCV hepatitis patients } \\
\text { before treatment. }\end{array}$ & $\begin{array}{l}\text { HCV hepatitis patients } \\
\text { after treatment. }\end{array}$ \\
\hline Mean & 15.03 & 8.6 & 10.33 \\
\pm SD & \pm 4.14 & \pm 1.1 & \pm 1.6 \\
\hline Control & t test & 9.9 & 6.56 \\
& p value & $<0.001$ & $<0.001$ \\
\hline HCV before & t test & & 2.46 \\
treatment & p value & & 0.02 \\
\hline
\end{tabular}


Table (6): Means, standard deviations and P value of serum levels of SOD, Total antioxidant capacity (TAC) and ox-LDL

\begin{tabular}{|c|c|c|c|c|c|}
\hline Parameters & Groups & Control & $\begin{array}{l}\mathrm{HCV} \\
\text { hepatitis } \\
\text { patients } \\
\text { before } \\
\text { treatment. }\end{array}$ & $\begin{array}{l}\text { HCV } \\
\text { hepatitis } \\
\text { patients } \\
\text { after } \\
\text { treatment. }\end{array}$ & $P$ value \\
\hline \multirow{3}{*}{ SOD $(\mathrm{U} / \mathrm{ml})$} & \multirow{3}{*}{$\begin{array}{l}\text { Mean } \\
\pm \text { SD }\end{array}$} & \multirow[t]{3}{*}{$15.03 \pm 4.14$} & \multirow[t]{3}{*}{$8.6 \pm 1.1$} & \multirow[t]{3}{*}{$10.33 \pm 1.6$} & P1 $<0.001$ \\
\hline & & & & & $\mathbf{P 2}<0.001$ \\
\hline & & & & & $\begin{array}{ll}\mathbf{P 3} & 0.02 \\
\end{array}$ \\
\hline \multirow{3}{*}{$\begin{array}{l}\text { TAC } \\
\text { (mmol/liter) }\end{array}$} & \multirow{3}{*}{$\begin{array}{l}\text { Mean } \\
\pm \text { SD }\end{array}$} & \multirow[t]{3}{*}{$1.61 \pm 0.26$} & \multirow[t]{3}{*}{$1.2 \pm 0.28$} & \multirow[t]{3}{*}{$2.2 \pm 0.38$} & P1 $<0.001$ \\
\hline & & & & & P2 $<0.001$ \\
\hline & & & & & $\mathbf{P 3}<0.001$ \\
\hline \multirow{3}{*}{$\begin{array}{l}\text { ox-LDL } \\
(\mu \mathrm{g} / \mathrm{L})\end{array}$} & \multirow{3}{*}{$\begin{array}{l}\text { Mean } \\
\pm \text { SD }\end{array}$} & \multirow{3}{*}{$\begin{array}{l}58.64 \pm \\
6.44\end{array}$} & \multirow{3}{*}{$\begin{array}{l}70.21 \pm \\
10.59\end{array}$} & \multirow[t]{3}{*}{$68.48 \pm 9.12$} & P1 $<0.001$ \\
\hline & & & & & $\mathbf{P 2}<0.001$ \\
\hline & & & & & $\begin{array}{lll}\text { P3 } & 0.1 \\
\end{array}$ \\
\hline
\end{tabular}

P1 (between control group and $\mathrm{HCV}$ hepatitis patients before treatment group), P2 (between control group and $\mathrm{HCV}$ hepatitis patients after treatment group)

\section{DISCUSSION}

Body measurement data (Anthropometric data) in adults are used to evaluate health and dietary status, disease risk, and body composition changes that occur over the adult lifespan. Anthropometric data of the patients were matching with the control group. In this study, the anthropometric data of all subjects were similar to the age group of American men (Fryar et al., 2010).

Obese persons were excluded from the study. Obesity is linked with a state of increased oxidative stress. Obesity is a principal causative factor in the development of metabolic syndrome. It is associated with a high cardiovascular risk. Ox-LDL is strongly and independently associated with classical cardiovascular risk factors (Freitas et al., 2018).

Changes in ox-LDL observed in this study were not due increased body weight. and P3 (between HCV hepatitis patients before treatment group and HCV hepatitis patients before treatment group).

Assay of Total anti-oxidant capacity measures a complex of non-enzymatic antioxidants present in blood, which include exogenous antioxidants such as ascorbic acid, $\alpha$ tocopherol, $\beta$ carotene and polyphenols. Ascorbic acid inhibits intracellular ROS generation and reduces the ethanol-induced inflammation in hepatocytes (Abhilash et al., 2013).

Assay of Total anti-oxidant capacityalso measures the endogenous antioxidants such as reduced glutathione, uric acid, and bilirubin.All patients were taking antioxidants including glutathione and ascorbic acid, as routine since they were diagnosed as HCV hepatitis patients. Taking antioxidants may explain the high level of blood total antioxidants in $\mathrm{HCV}$ hepatitis patients as compared to the control group.

Serum levels of ox-LDL were significantly high in $\mathrm{HCV}$ hepatitis 
patients as compared to control group. Antioxidants supplementations and direct antiviral drugs did not affect the levels of ox-LDL in HCV hepatitis patients.OxLDL was used as a marker of oxidative stress in this study. Ox-LDL is a stable marker molecule with longer half-live than free radicalsasmalondialdehyde. OxLDL can potentially contribute to the pathogenesis of liver diseases, kidney diseases, uremia, cardiovascular disease, and inflammation (Russ et al., 2015).

Hepatitis $\mathrm{C}$ virus is a lipid-enveloped virion particle that causes infection to the liver, and as part of its life cycle, it disrupts the host lipid metabolic machinery, particularly the cholesterol synthesis pathway. The current directacting antiviral agents have increased the cure rate of HCV infection. Viral the host genetic backgrounds influence both the immune response and lipid metabolism. Cholesterol and its derivatives such as oxysterols might modulate and potentialize the hepatic innate immune response generated against $\mathrm{HCV}$. The impairment of the HCV life cycle modulated by serum cholesterol could be relevant for the clinical management of HCV-infected patients before and after treatment (González-Aldaco et al., 2018).

LDL lipoperoxidation leads to modifications in apolipoprotein B-100 and lipids. Ganini and Mason (2014) reported the lack of protection of $\alpha$-tocopherol on the Apo B-100 and lipid free radical formation by lipooxygenases. This may explain the failure of vitamin $\mathrm{E}$ as a cardiovascular protective agent for humans. In addition, it may explain the high levels of ox-LDL in hepatitis patients although they are on vitamin $\mathrm{E}$ as a supplement.

The significant high levels of ox-LDL reported in this study, may be a factor in the pathogenesis $\mathrm{HCV}$ hepatitis and $\mathrm{HCV}$ liver cirrhosis. Ox-LDL in serum of HCV patients may be a result of $\mathrm{HCV}$ induced oxidative stress in infected cells or it may be due to decreased endogenous production of antioxidants.

Oxidative stress results induces phosphorylation of eIF $2 \alpha$ resulting in inhibition of global (including that of viral) protein synthesis and constitutes an important defense against virus infection. ROS; induced by $\mathrm{HCV}$ inhibit virus replication without affecting stability of its RNA genome. ROS can induce viral genome heterogeneity, which facilitates viral escape during treatment and probably escape from the immune system (Lozano-Sepulveda et al., 2015).

ROS induce fixed chemical modification of the proteins and lipids in plasma LDL transforming it to the abnormal ox-LDL. Oxidative changes in amino acids as well as proteolysis and cross-links of apolipoprotein B occur that result in extensive alteration in the protein composition and structure forming carbonylatedproteins. These protein oxidations should be treated before they are initiated at the early stage of $\mathrm{HCV}$ infection (Abou-El-Makarem et al., 2014).

Oxidized low-density lipoprotein is a key pathogenic determinant of vascular atherosclerosis. Moreover, increased levels of ox-LDL are associated with hepatocellular injury in experimental cholestasis and fibrosis (Karadeniz et al., 2008). 
Ho et al., 2019 stated that free cholesterol is colocalized with ox-LDL in the wall of portal vein, and was associated with lumen narrowing, plaque formation, endothelium deformation, and portal venous inflammation in experimental rats. The inflammation was evidenced by the colocalization of Kupffer cells, IL- $1 \beta$ and the expression of LOX-1. Ruptured plaque was closely associated with portal venous inflammation. Moreover, free cholesterol and ox-LDL accumulation in periportal and sinusoidal fibrosis, which was associated with regional stellate cell activation and chicken-wire fibrosis. Their findings reveal a direct association between cholesterol accumulation, portal venous inflammation and fibrosis in nonalcoholic fatty liver disease (Ho et al., 2019).

Serum levels of extracellular SOD were significantly low in $\mathrm{HCV}$ hepatitis patients before and after treatment as compared to the control group.

Extracellular SOD is responsible for the dismutation of the superoxide radical produced in the extracellular space Extracellular superoxide SOD is expressed by inflammatory cells, including macrophages and neutrophils.Its gene is located on chromosome 4 (4p15.2Gottfredsen et al., 2014).

The significant low levels of extracellular SOD observed in this study may be due to genetic predisposition of patients, or it may be due to permanent effects of HCV infection and not restored after virological clearance. Khedr et al. (2019) have reported increase in the levels of glutathione peroxidase and a decrease in the levels of malondialdehyde in children with chronic hepatitis $\mathrm{C}$ after treatment with interferon.

New antioxidants as well as inducers of antioxidant enzymes; $\mathrm{Mn} /$ superoxide dismutase and catalase, may be helpful in prevention of formation of ox-LDL (Robbins and Zhao, 2011).

\section{CONCLUSION}

Ox-LDL is a stable marker molecule of oxidative stress. ROS produce oxidative changes in proteins and lipids in LDL. There was a highly significant increase in serum ox-LDL levels in HCV hepatitis patients as compared to the control group .Direct-acting antiviral agents did not normalize serum levels of ox-LDL

Treatment increased slightly the levels of serum SOD, but it did not restore the levels to those of the control groupalthough of the sustained virological clearance.

\section{REFERENCES}

1. Abhilash PA, HarikrishnanR and Indira M (2013): Ascorbic acid is superiortosilymarin in the recovery of ethanol-induced inflammatory reactions inhepatocytes of guinea pigs. J Physiol Biochem., 69: 785-798.

2. Abou-El-Makarem MM, Moustafa MM, Fahmy MA, Abdel-Hamed AM, El-Fayomi KN and Darwish MA (2014): Evaluation of Carbonylated Proteins in Hepatitis C Virus Patients. Mod Chem Appl., 2:130-137.

3. Choi J (2012): Oxidative stress, endogenous antioxidants, alcohol, and hepatitis $\mathrm{C}$ : pathogenic interactions and therapeutic considerations. Free Radic Biol Med., 52(7): 1135-1150.

4. Freitas MCP, Fernandez DGE, Cohen D, Figueiredo-Neto AM, Maranhão RC and Damasceno NRT (2018): Oxidized and electronegative low-density lipoprotein as potential biomarkers of cardiovascular risk in 
obese adolescents. Clinics (Sao Paulo), 73:e189.

5. Fryar CD, Quipping $G$ and Ogden $C L$ (2010): Anthropometric Reference Data for Children and Adults: United States, 20072010. Vital and health statistics, Series 11, Number 252.

6. Ganini D and Mason RP (2014): Absence of an effect of vitamin $\mathrm{E}$ on protein and lipid radical formation during lipoperoxidation of LDL by lipoxygenase. Free Radic Biol Med., 76:661-668.

7. González-Aldaco K, Torres-Reyes LA, Ojeda-Granados C, José-Ábrego A, Fierro NA and Román S (2018): Immunometabolic Effect of Cholesterol in Hepatitis C Infection: Implications in Clinical Management and Antiviral Therapy. Ann Hepatol., 17(6):908919.

8. Gottfredsen RH, Goldstrohm DA, Hartney JM, Larsen UG, Bowler RP and Petersen SV (2014): The cellular distribution of extracellular superoxide dismutase in macrophages is altered by cellular activation but unaffected by the naturally occurring R213G substitution. Free Radic Biol Med., 69:348-56.

9. Ho CM, Ho SLJeng YM, Lai YS, Chen YH, Lu SC, Chen HL, Chang PO, Hu RH and Lee PH (2019): Accumulation of free cholesterol and oxidized low-density lipoprotein is associated with portal inflammation and fibrosis in nonalcoholic fatty liver disease. J Inflamm (Lond), 16:Aricle 7.

10. Holley AK, Bakthavatchalu V, VelezRoman JM and St. Clair DK (2011): Manganese Superoxide Dismutase: Guardian of the Powerhouse. Int J Mol Sci., 12: 7114 7162 .

11. Holvoet $P$, Mertens $A$, Verhamme $P$, Bogaerts $K$, Beyens $G$, Verhaeghe $R$, Collen D, Muls $E$ and Van de Werf F (2001): Circulating oxidized LDL is a useful marker for identifying patients with coronary artery disease. Arterioscler Thromb Vasc Biol., 21(5):844-848.
12. Janardhan SV and Reau NS (2015): Should NS5A inhibitors serve as the scaffold for alloral anti-HCV combination therapies. Hepat Med., 7:11-20.

13. Karadeniz G, Acikgoz S, Tekin IO, Tascýlar O, Gun BD and Cömert $M$ (2008): Oxidized low-density-lipoprotein accumulation is associated with liver fibrosis in experimental cholestasis. Clinics (Sao Paulo)., 63:531-540.

14. Khedr MA, El-Araby HA, Konsowa HA, Sokar SS, Mahmoud MF, Adawy NM and Zakaria HM (2019): Glutathione peroxidase and malondialdehyde in children with chronic hepatitis C. Clin Exp Hepatol. 2019 Mar;5(1):81-87.

15. Koracevic D, Koracevic G, Djordjevic V, Andrejevic S and Cosic V (2001): Method for the measurement of antioxidant activity in human fluids. J Clin Pathol., 54: 356-361.

16. Li H, Huang MH, Jiang JD and Peng ZG (2018): Hepatitis C: from inflammatory, pathogenesis, to antianflammatory/hepatoprotective therapy. World J Gastroenterol., 24(47):5297-5311.

17. Lin SJ, Shyue SK, Shih MC, Chu TH, Chen YH, Ku HH, Chen JW, Tam KB and Chen YL (2007): Superoxide dismutase and catalase inhibit oxidized low-density lipoprotein-induced human aortic smooth muscle cell proliferation: role of cell-cycle regulation, mitogen-activated protein kinases, and transcription factors. Atherosclerosis, 190(1): 124-134.

18. Lozano-Sepulveda SA, Bryan-Marrugo OL, Cordova-Fletes C, Gutierrez-Ruiz MC and Rivas-Estilla AM (2015): Oxidative stress modulation in hepatitis $\mathrm{C}$ virus infected cells. World J Hepatol., 7(29): 2880-2889.

19. Makino J, Asai R, Hashimoto M, Kamiya T, Hara H, Ninomiya M, Koketsu $M$ and Adachi T (2016): Suppression of EC-SOD by oxLDL During Vascular Smooth Muscle Cell Proliferation. J Cell Biochem., 117(11):2496-2505.

20. Nishikimi M, RaoNA andYagi K (1972): The occurrence of superoxide anion in the reaction of reduced phenazinemethosulphate 
and molecular oxygen. Biochem. Biophys Res Co., 46: 849-864.

21. Pol S, Corouge $M$ and Vallet-Pichard $A$ (2016): Daclatasvir-sofosbuvir combination therapy with or without ribavirin for hepatitis $\mathrm{C}$ virus infection: from the clinical trials to real life. Hepat Med., 8:21-26.
22. Robbins D and Zhao Y (2011): The role of manganese superoxide dismutase in skin cancer. Enzyme Res., 2011:492-95.

23. Russ KB, Stevens TM and Ashwani KS (2015): Acute Kidney Injury in Patients with Cirrhosis. J ClinTranslHepatol; 3(3): 195204. 
تقييم البرونين الدهني منخفض الكثافة المؤكسد و وانزيم

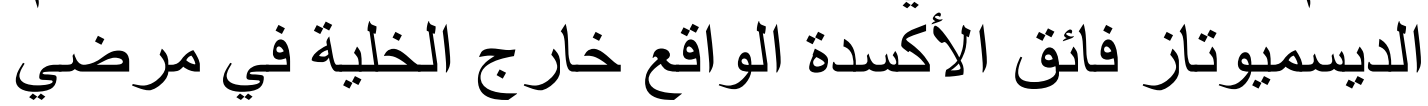

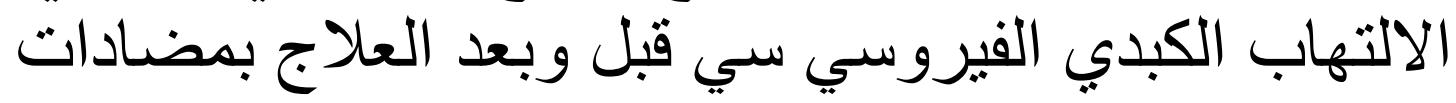
الفيروسات المباشرة

محمود محمد أبو المكارم، عبدالعزيز عبدالرحمن النقلي، سيد فاروق محمد*، إبراهيم حسن محمد، أحمد محروس أحمد إبراهيم قسمي الكيمياء الحيوية الطبية و الأمراض المتوطنةث، كلية الطب، جامعة|لأزهر

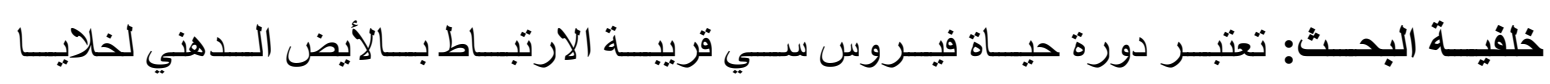

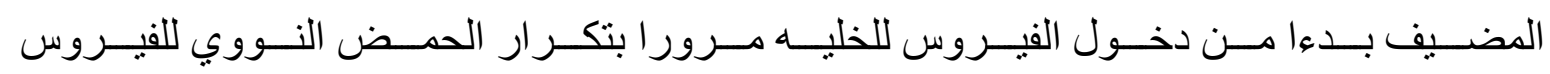
و انتاج جسيمات الفيروس

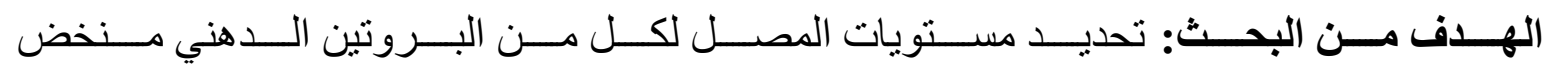

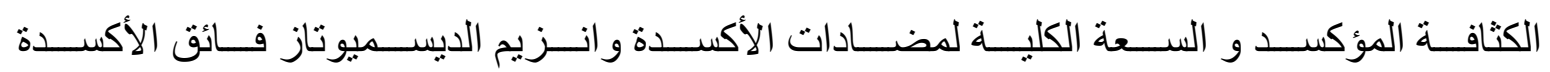

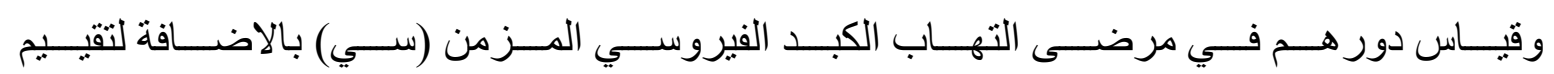
تأثير العلاج بمضادات الفيروسات المباثر علي مستوياتهم

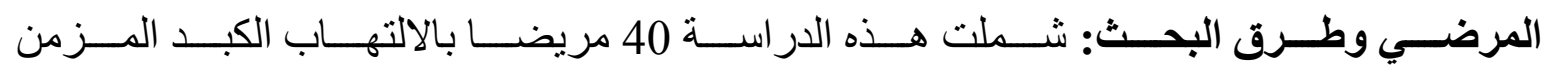

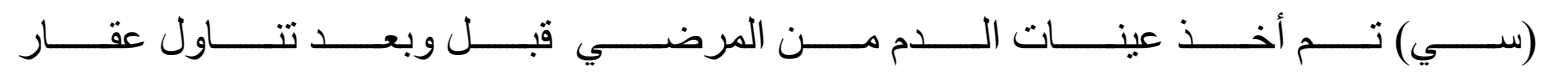

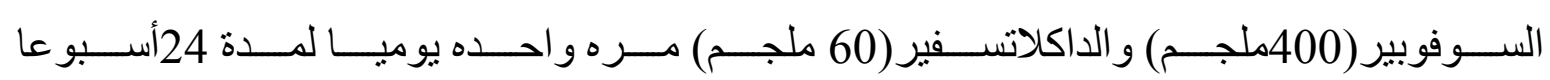
كما شملت الدراسة أيضا 40 متطو عا كمجمو عه ظابطة مرجعية.

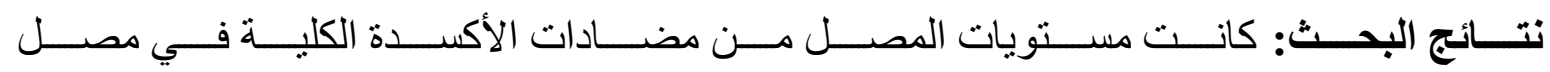

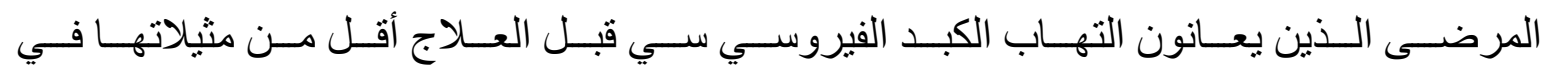

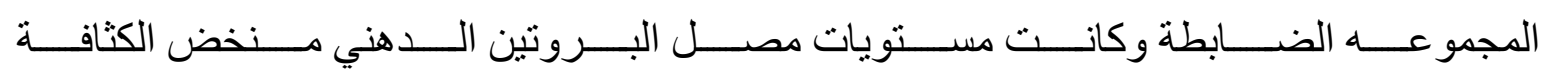

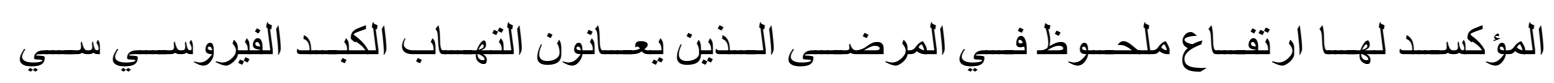

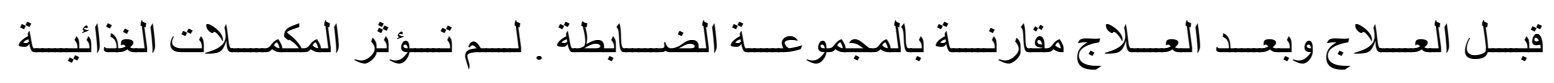

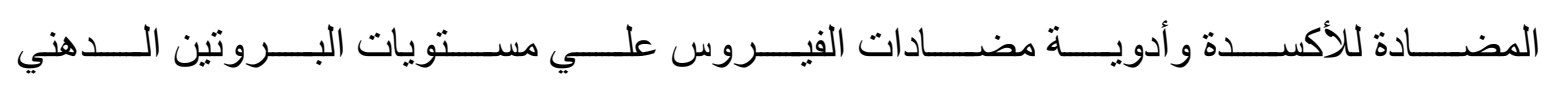

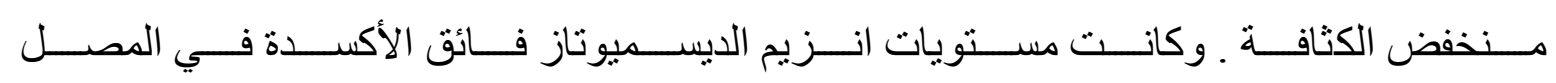




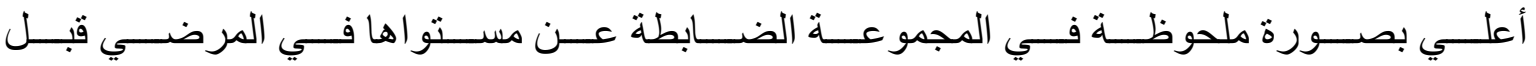

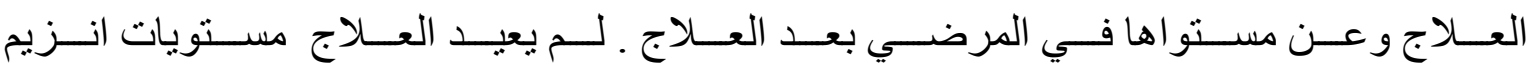

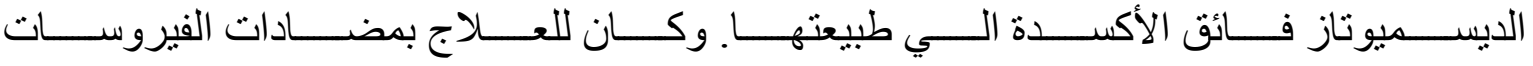
استجابة فيروسية مستمرة في المجمو عات المختارة.

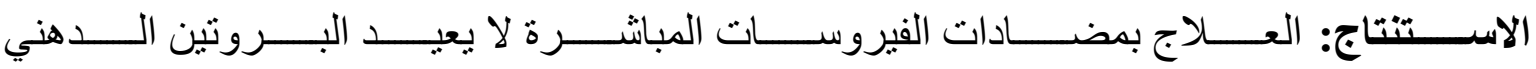

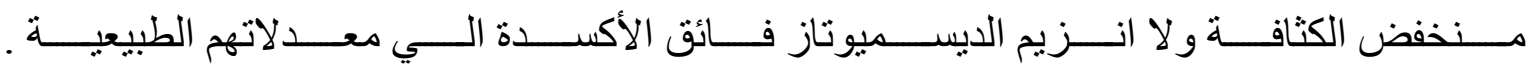

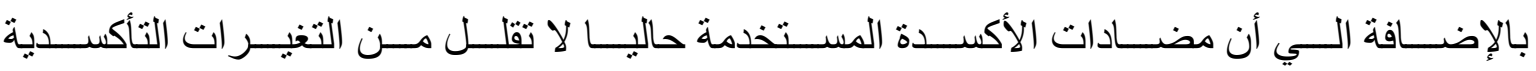
في البروتين الدهني منخفض الكثافة.

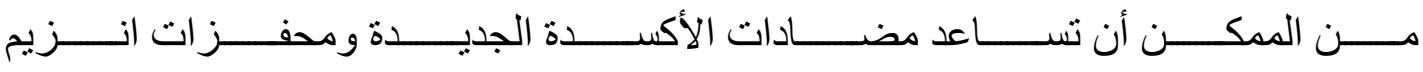

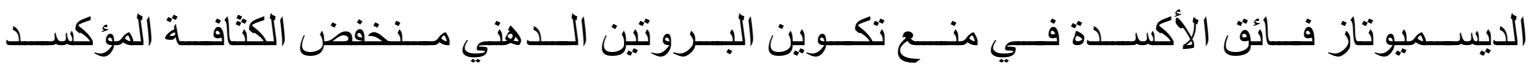
ومن الممكن أن يساعد في علاج الإلتهاب الكبدي الفيروسي من النوع سي. 